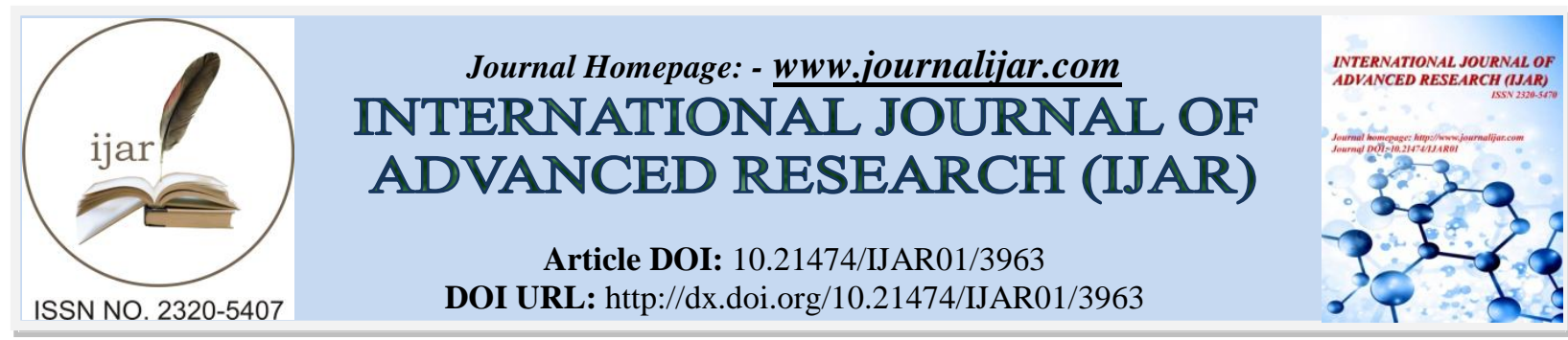

RESEARCH ARTICLE

\title{
PROBIOTIC NON LACTIC ACID BACTERIA: STUDY OF BACTERIOCIN FOR THE ANTAGONISTIC ACTIVITY.
}

Rashmi. D and Sharmila. T.

Department of Microbiology and Biotechnology, Bangalore University, Bangalore- 560056, Karnataka, India.

\section{Manuscript Info}

Manuscript History

Received: 11 February 2017

Final Accepted: 02 March 2017

Published: April 2017

Key words:-

Antagonistic activity, Bacteriocins, Non lactic acid bacteria, Kirby-bauer disc diffusion.

\section{Abstract}

Bacteriocins are very useful as therapeutic agents. They act as an important and safer components as preservative and hence find their application in a wide range of medicine, agriculture, food and dairy products. Isolation of bacteriocins and its significant application has remained a challenging task. Production of bacteriocins of beneficial grade and their utilization as antibiotics and in food grade products without any harmful side effects also appear to be a tedious work. This work was initiated by isolation of non lactic acid bacteria from various food materials like pulses and cow's milk, morphological identification by colony characteristics and microscopic examination by Gram's staining. Qualitative identification of non lactic acid bacteria by catalase test. Bacteriocins production was detected by antimicrobial activity test against the indicator organisms by Kirby bauer disc diffusion method. Here we are presenting the results of the identification tests of the isolated bacteria and that of the antimicrobial studies. Future prospective includes the optimization of cultural, nutritional parameters and use of inducers to enhance the production, purification and characterization of bacteriocins. Significance of bacteriocins would be exploited in replacing the use of antibiotics and as preservative in food industries.

Copy Right, IJAR, 2017,. All rights reserved.

\section{Introduction:-}

The viable microbial food supplements which beneficially influence the health of humans are known as probiotics. Antibacterial activity is one of the important probiotic properties for a strain to be a functional probiotic. Bacteria are being used as probiotic supplements for use in animal feeds, for human dietary supplements as well as in registered medicines. Their heat stability and ability to survive the gastric barrier makes them attractive as food additives and this use is now being taken forward. Bacillus or spore probiotics are being used extensively in humans as dietary supplements, in animals as growth promoters and competitive exclusion agents in aquaculture. Bacteriocins are ribosomally synthesized, proteinaceous compounds that inhibit the growth of closely related bacteria. Even within the subcategory of bacteriocins, the peptides vary significantly in terms of the gene cluster responsible for expression, and chemical and structural composition. In 1925, Gratia demonstrated the inhibitory activity of bacteriocin which was later determined to be colicin V (Cascales et.al; 2007). After, in 1928 nisin activity was reported by Rogers (Lubelski et.al; 2007). Bacteriocin has the ability to target a subgroup of pathogenic bacteria in a complex bacterial community. This has gained a potential application in medicine, agriculture and food where 
the maintenance of a normal microbiome is beneficial in replacing the use of antibiotics, chemical preservatives which are used in increasing the shelf life of the food material. The probiotic qualities of Bacillus species is found to be good for the safer usage of heat resistant, non-pathogenic cultures devoid of cytK, hdlD and nhe1 virulence genes are identified by fatty acid profiling and 16S rRNA sequencing (Prakash.H.M; 2014). The cultures showed 70-80\% survival under simulated gastrointestinal condition which was confirmed by H+ ATPase production. The amount of $\mathrm{H}+$-ATPase was increased by more than 2-fold when grown at $\mathrm{pH} 2$ which support for the acid tolerance ability of Bacillus isolates. The study also examined the influence of acidic $\mathrm{pH}$ on cellular fatty acid composition of Bacillus species. The cultures exhibit various probiotic functional properties which allow their use in industries and possible health benefits. Pyocin, lectin-like bacteriocins from Pseudomonas aeruginosa consists of tandem mannose binding domains and display a genus specific killing activity (McCaughey et.al; 2014). Pyocin L1 targets the susceptible strains of closely related species through recognition of the common polysaccharide antigen (CPA) of $P$. aeruginosa lipopolysaccharide that is predominantly a homopolymer of D-rhamnose. Biophysical and structural analysis shows that the recognition of CPA occurs through the C-terminal carbohydrate binding domain of pyocin L1 and this interaction is a prerequisite for bactericidal activity. Bacteriocins act as an alternative to antibiotics with wide range of action on antibiotic resistant pathogens and nosocomial infectious organisms (Paul D Cotter et.al; 2013). Use of microcins is a possible alternative to control gram negative bacteria. Application of bacteriocin molecules on food surface requires much lower amounts of bacteriocin, compared to the application in whole food volume. Bacteriocin is replacing chemical preservatives as it is considered as GRAS status without causing any adverse effect on human consumption. It helps in biopreservation, shelf-life extension, clinical antimicrobial action and control of fermentation microflora or anaerobic respiration of microorganisms in food and clinical samples. In food, partially purified or purified concentrates of bacteriocin can be added that acts against closely related and some spoilage and disease causing gram positive bacteria (Deshmukh.P.V et.al; 2013, E.M.Balciunas et.al; 2012, Hemalatha.S et.al; 2010). They are proteinaceous toxins produced by bacteria to inhibit the growth of similar or closely related bacterial strain(s). They are typically considered to be narrow spectrum antibiotics (Farkas-Himsley H 1980).

\section{Materials And Methods:-}

Isolation of bacteriocin producing bacteria:-

Pulses like Soya bean (Glycine max), Desi/ Black chana (Vigna mungo), Kabuli chana (Cicer arietinum) and cow's milk were used for isolation of bacteria. Fermented chunks (pulses) were made from fermented mashed pulse by soaking them in water, grinding and finally drying the small chunks in the sun. For isolation of bacteria, fermented material was soaked in $10 \mathrm{ml}$ of distilled water at $27^{\circ} \mathrm{C}$ for $15 \mathrm{mins}$. After crushing in sterilized mortar with pestle, it was serially diluted in the range from $10^{-1}$ to $10^{-7}$. Cow's milk was taken aseptically in a sterile bottle. Raw milk and pasteurized milk was used for isolation of bacteria. $1 \mathrm{ml}$ of raw and pasteurized milk was serially diluted in the range from $10^{-1}$ to $10^{-7}$. Isolation of bacteria was carried out by pour plate method on nutrient agar at $37{ }^{\circ} \mathrm{C}$ for $24-48 \mathrm{hrs}$. The isolates were primarily screened for bacteriocin or bacteriocin like substance production by disc diffusion method against indicator organisms and characterized using Gram's staining technique.

\section{Indicator bacteria:-}

The serious food-borne pathogens and spoilage-causing microorganisms were procured from Microbial Type Culture Collection, Chandigarh, India, like E.coli (MTCC no: 10312) and S.aureus (MTCC no: 1430) to study the antagonistic pattern of the isolates. Further studies of bacteriocin or bacteriocin like substances production and activity were performed by Kirby bauer disc diffusion method.

\section{Screening:-}

Screening of isolates was done through disc diffusion assay as given below and the size of clear zone of inhibition was recorded against the indicator bacteria to select the best strain.

\section{Disc diffusion assay:-}

Isolated bacterial strains were grown in nutrient broth separately, incubated at $37^{\circ} \mathrm{C}$ for 3days in shaking condition at $150 \mathrm{rpm}$. The cultures were centrifuged at $10000 \mathrm{rpm}$ for $5 \mathrm{~min}$ and the supernatant was collected. $24 \mathrm{hrs}$ fresh culture of indicator bacteria was prepared and the cell density was adjusted to $A=1.0$ at $625 \mathrm{~nm}$ according to Mc Farland standard. A volume of $100 \mu \mathrm{l}$ of inoculum of each indicator bacteria was swabbed on prepoured sterilized nutrient agar plates using sterilized cotton bud. The sterile discs of $5 \mathrm{~mm}$ in diameter were prepared using Whatmann no 1 filter paper were placed on bacteria swabbed nutrient agar plates and $10 \mu 1$ of culture supernatant were poured in each disc. The plates were incubated at $37^{\circ} \mathrm{C}$ for $24 \mathrm{hrs}$ and the clear zones formed around the disc were measured. 


\section{Results And Discussion:-}

1. In total, 74 colonies with different morphological features were isolated of which 26 isolates from soya bean (SB), 12 isolates from black chana (BC), 21 isolates from kabuli chana (KC) and 15 isolates from cow's milk.

2. During primary screening against the indicator organism both E.coli \& S.aureus showed positive growth in control plates.

3. Out of 74 isolates, during primary screening the supernatants of 7 isolates from soya bean, 6 isolates from black chana, 2 isolates from kabuli chana and 5 isolates from cow's milk showed a clear zone of inhibition against E.coli but did not produce zone against S.aureus. The screening of isolates by disc diffusion assay was further repeated for consecutive two times. After repetitive successive screening only 3 isolates from pulses and 3 isolates from cow's milk showed the same activity which was measured through consistent zone of inhibition production including the disc with is tabulated.

4. Gram's staining of the 20 isolates from the primary screened bacteria was done. Among 20 isolates, 3 were $+v e$ cocci, 5 were +ve coccobacilli, 2 were -ve coccobacilli and 10 were +ve bacilli.

Table 01:- Isolates from soya bean for primary screening

\begin{tabular}{|l|l|l|}
\hline Sl.no & Zone of inhibition (in mm) & \multicolumn{2}{l|}{ S.aureus } \\
\hline & E.coli & + \\
\hline Control & + & -- \\
\hline SB 1 & -- & -- \\
\hline SB 2 & -- & -- \\
\hline SB 3 & -- & -- \\
\hline SB 4 & -- & -- \\
\hline SB 5 & -- & -- \\
\hline SB 6 & -- & -- \\
\hline SB 7 & -- & -- \\
\hline SB 8 & -- & -- \\
\hline SB 9 & $\mathbf{9}$ & -- \\
\hline SB 10 & 7 & -- \\
\hline SB 11 & $\mathbf{7}$ & -- \\
\hline SB 12 & -- & -- \\
\hline SB 13 & -- & -- \\
\hline SB 14 & -- & -- \\
\hline SB 15 & -- & -- \\
\hline SB 16 & $\mathbf{7}$ & -- \\
\hline SB 17 & $\mathbf{7}$ & -- \\
\hline SB 18 & $\mathbf{7}$ & -- \\
\hline SB 19 & -- & -- \\
\hline SB 20 & -- & -- \\
\hline SB 21 & -- & -- \\
\hline SB 22 & -- & -- \\
\hline SB 23 & -- & -- \\
\hline SB 24 & -- & -- \\
\hline SB 25 & -- & -- \\
\hline SB 26 & $\mathbf{1 0}$ & \\
\hline & & \\
\hline
\end{tabular}

Table 02:- Isolates from black chana for primary screening

\begin{tabular}{|l|l|l|}
\hline Sl.no & Zone of inhibition (in mm) & S.aureus \\
\hline & E.coli & + \\
\hline Control & + & -- \\
\hline BC 1 & $\mathbf{8}$ & -- \\
\hline BC 2 & $\mathbf{7}$ & -- \\
\hline BC 3 & $\mathbf{7}$ & -- \\
\hline BC 4 & -- & -- \\
\hline BC 5 & $\mathbf{7}$ & \multicolumn{2}{|l|}{} \\
\hline
\end{tabular}




\begin{tabular}{|l|l|l|}
\hline BC 6 & 9 & -- \\
\hline BC 7 & $\mathbf{7}$ & -- \\
\hline BC 8 & -- & -- \\
\hline BC 9 & -- & -- \\
\hline BC 10 & -- & -- \\
\hline BC 11 & -- & -- \\
\hline BC 12 & -- & -- \\
\hline
\end{tabular}

Table 03:- Isolates from kabuli chana for primary screening.

\begin{tabular}{|l|l|l|}
\hline Sl.no & Zone of inhibition (in $\mathrm{mm}$ ) & \multicolumn{2}{l|}{ S.aureus } \\
\hline & E.coli & + \\
\hline Control & + & -- \\
\hline KC 1 & -- & -- \\
\hline KC 2 & -- & -- \\
\hline KC 3 & -- & -- \\
\hline KC 4 & -- & -- \\
\hline KC 5 & -- & -- \\
\hline KC 6 & -- & -- \\
\hline KC 7 & -- & -- \\
\hline KC 8 & -- & -- \\
\hline KC 9 & -- & -- \\
\hline KC 10 & -- & -- \\
\hline KC 11 & -- & -- \\
\hline KC 12 & -- & -- \\
\hline KC 13 & -- & -- \\
\hline KC 14 & 7 & -- \\
\hline KC 15 & 7 & -- \\
\hline KC 16 & -- & -- \\
\hline KC 17 & -- & -- \\
\hline KC 18 & -- & -- \\
\hline KC 19 & -- & -- \\
\hline KC 20 & -- & -- \\
\hline KC 21 & -- & \\
\hline
\end{tabular}

Table 04:- First repeat for the consecutive screening

\begin{tabular}{|l|l|l|}
\hline Sl.no & Zone of inhibition (in mm) & S.aureus \\
\hline & E.coli & + \\
\hline Control & + & -- \\
\hline SB 9 (P1) & $\mathbf{9}$ & -- \\
\hline SB 10 (P2) & $-(<7)$ & -- \\
\hline SB 11 (P3) & $-(<7)$ & -- \\
\hline SB 16 (P4) & $-(<7)$ & -- \\
\hline SB 17 (P5) & $-(<7)$ & -- \\
\hline SB 18 (P6) & $-(<7)$ & -- \\
\hline SB 26 (P7) & $\mathbf{1 0}$ & -- \\
\hline BC 1 (P8) & -- & -- \\
\hline BC 2 (P9) & -- & -- \\
\hline BC 3 (P10) & -- & -- \\
\hline BC 5 (P11) & -- & -- \\
\hline BC 6 (P12) & $\mathbf{9}$ & -- \\
\hline BC 7 (P13) & $-(<7)$ & -- \\
\hline KC 14 (P14) & $-(<7)$ & -- \\
\hline KC 15 (P15) & $-(<7)$ & \\
\hline
\end{tabular}


Table 05:- Second repeat for the consecutive screening

\begin{tabular}{|l|l|l|}
\hline S1.no & Zone of inhibition (in $\mathrm{mm}$ ) & S.aureus \\
\hline & E.coli & + \\
\hline Control & + & -- \\
\hline P1 & $\mathbf{9}$ & -- \\
\hline P2 & $-(<7)$ & -- \\
\hline P3 & $-(<7)$ & -- \\
\hline P4 & $-(<7)$ & -- \\
\hline P5 & $-(<7)$ & -- \\
\hline P6 & $-(<7)$ & -- \\
\hline P7 & $\mathbf{1 0}$ & -- \\
\hline P8 & -- & -- \\
\hline P9 & -- & -- \\
\hline P10 & -- & -- \\
\hline P11 & -- & -- \\
\hline P12 & $\mathbf{7}$ & -- \\
\hline P13 & $-(<7)$ & -- \\
\hline P14 & $-(<7)$ & -- \\
\hline P15 & $-(<7)$ & \\
\hline
\end{tabular}

Table 06:- Isolates from cow's milk for primary screening

\begin{tabular}{|l|l|l|}
\hline Sl.no & Zone of inhibition $($ in $\mathrm{mm})$ & \multicolumn{2}{l|}{} \\
\hline & E.coli & S.aureus \\
\hline Control & + & + \\
\hline CM1 & $\mathbf{9}$ & -- \\
\hline CM2 & $\mathbf{8}$ & -- \\
\hline CM3 & $-(<7)$ & -- \\
\hline CM4 & $-(<7)$ & -- \\
\hline CM5 & $\mathbf{9}$ & -- \\
\hline CM6 & $-(<7)$ & -- \\
\hline CM7 & $\mathbf{1 2}$ & -- \\
\hline CM8 & $\mathbf{7}$ & -- \\
\hline CM9 & -- & -- \\
\hline CM10 & -- & -- \\
\hline CM11 & -- & -- \\
\hline CM12 & -- & --- \\
\hline CM13 & $-(<7)$ & -- \\
\hline CM14 & $-(<7)$ & -- \\
\hline CM15 & $-(<7)$ & -- \\
\hline
\end{tabular}

Table 07:- Repeated for the consecutive screening

\begin{tabular}{|l|l|l|}
\hline Sl.no & Zone of inhibition (in $\mathrm{mm}$ ) \\
\hline & E.coli & S.aureus \\
\hline Control & + & + \\
\hline CM1 & $\mathbf{9}$ & -- \\
\hline CM2 & $\mathbf{8}$ & -- \\
\hline CM5 & $\mathbf{9}$ & -- \\
\hline CM7 & $\mathbf{1 2}$ & -- \\
\hline CM8 & $\mathbf{7}$ & -- \\
\hline
\end{tabular}

$+\rightarrow$ Positive growth $--\rightarrow$ No growth (No zone of inhibition)

- $\rightarrow$ scanty growth (thin zone of inhibition) 
Table 06: Gram's staining of the isolates showing positive antagonistic activity

\begin{tabular}{|c|c|c|}
\hline Sl.no & Gram's staining & Shape \\
\hline $\mathrm{P} 1$ & +ve & Cocci, cluster \\
\hline $\mathrm{P} 2$ & $+\mathrm{ve}$ & Coccobacilli \\
\hline P3 & -ve & Coccobacilli \\
\hline $\mathrm{P} 4$ & $+\mathrm{ve}$ & Bacilli \\
\hline P5 & +ve & Coccobacilli \\
\hline P6 & $+\mathrm{ve}$ & Cocci \\
\hline P7 & +ve & Coccobacilli, cluster \\
\hline P8 & +ve & Bacilli \\
\hline P9 & $+\mathrm{ve}$ & Bacilli \\
\hline $\mathrm{P} 10$ & $+\mathrm{ve}$ & Bacilli \\
\hline $\mathrm{P} 11$ & $+\mathrm{ve}$ & Bacilli \\
\hline P12 & + ve & Bacilli \\
\hline $\mathrm{P} 13$ & $+\mathrm{ve}$ & Bacilli \\
\hline $\mathrm{P} 14$ & +ve & Bacilli \\
\hline $\mathrm{P} 15$ & +ve & Bacilli \\
\hline CM1 & $+\mathrm{ve}$ & Bacilli \\
\hline CM2 & -ve & Coccobacilli \\
\hline CM5 & $+\mathrm{ve}$ & Coccobacilli \\
\hline CM7 & $+\mathrm{ve}$ & Coccobacilli \\
\hline CM8 & $+\mathrm{ve}$ & Cocci \\
\hline
\end{tabular}

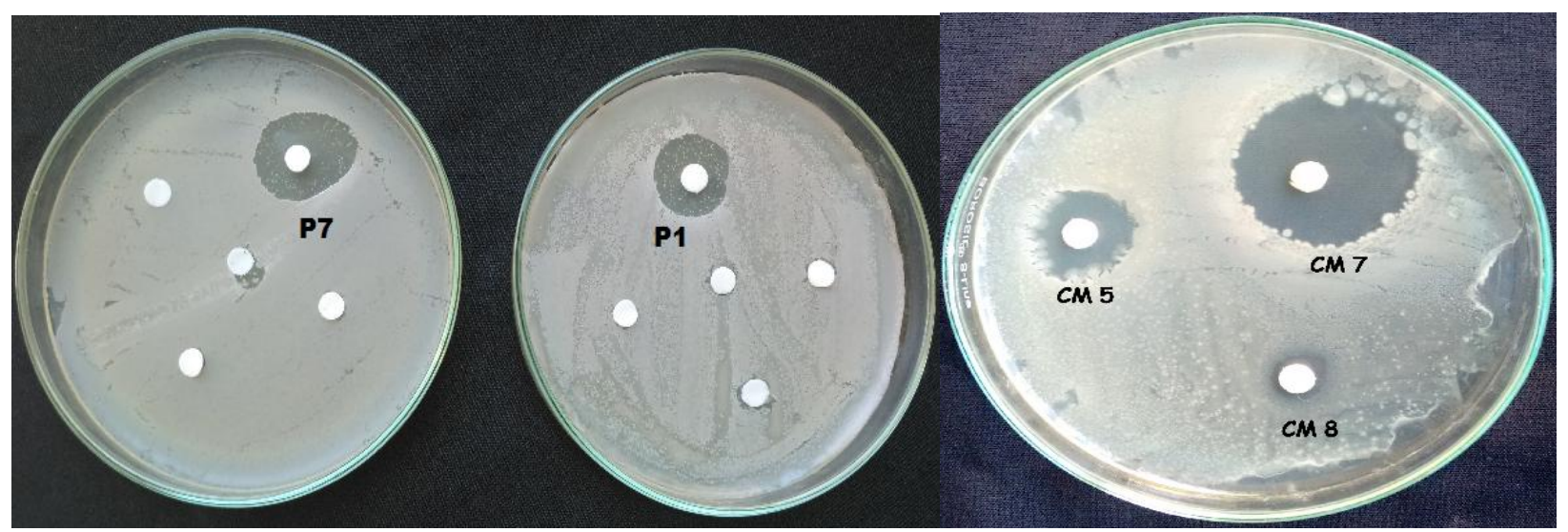

Fig.1:- Inhibitory spectrum against E.coli showing the clear zone of inhibition from the supernatants isolated from pulses coded as P1 \& P7 and cow's milk coded as CM5, CM7 \& CM8.

\section{Conclusion:-}

The present study clearly shows the bacteriocin produced from the non lactic acid bacteria from pulses and cow's milk are very effective against E.coli, a gram negative, facultative anaerobe, rod shaped, coliform which leads to health problems in humans. The bacteria isolated from probiotics showed a significant production of antimicrobial substances which have the ability to inhibit the growth of the food spoilage bacteria. The study focuses on the production of bacteriocins not only by lactic acid bacteria but also by non lactic acid bacteria which further prospective of optimization, characterization and purification of the bacteriocins. The bacteria from probiotic sample that inhibited certain pathogens by producing bacteriocin may be beneficial for probiotic culture to be triumphant in colonizing and to contend with the pathogens.

\section{Conflict of interest statement:-}

We declare that we have no conflict of interest. 


\section{Acknowledgement:-}

The authors would like to extend their sincere thanks and appreciation to the Department of Microbiology and Biotechnology, Bangalore University for providing adequate lab facilities and Dr. Muralidhar T, HOD, Department of Biotechnology, Dayananda Sagar Institutions (DSI), Bangalore for his immense support and providing the required instrument needed for the study.

\section{References:-}

1. Balciunas,E.M, Martinez, F.A.C, Todorov, S.D, de Melo Franco, B.D.G, Converti, A \& de Souza Oliveira, R.P (2012). Novel biotechnological applications of bacteriocins: A review. Elsevier Ltd, Food Control 32, $134-142$.

2. Brito, M.A.V.P, Somkuti, G.A \& Renye Jr, J.A (2010). Production of antilisterial bacteriocins by Staphylococci isolated from bovine milk. American Dairy Science Association. 94:1194-1200.

3. Cinzia Marianelli, Noemi Cifani, Paolo Pasquali (2010). Evaluation of antimicrobial activity of probiotic bacteria against Salmonella enterica subsp. enterica serovar typhimurium 1344 in a common medium under different environmental conditions. Elsevier Masson SAS, 673-680.

4. Deshmukh, P. V \& Thorat, P. R (2013). Bacteriocins: A new trend in antimicrobial food packaging, Review Paper, International Journal of Advanced Research in Engineering and Applied Science.

5. Hemalatha, S \& Shanthi, S (2010). In vitro characterization of bacteriocin producing Bacillus subtilis from milk samples. African Journal of Microbiology Research Vol. 4(19), 2004-2010.

6. McCaughey LC, Grinter R, Josts I, Roszak AW, Waløen KI, et al. (2014). Lectin-Like Bacteriocins from Pseudomonas spp. Utilise D-Rhamnose Containing Lipopolysaccharide as a Cellular Receptor Plos Pathog 10(2).

7. Paul D. Cotter, Paul Ross, R \& Colin Hill (2013). Bacteriocins - a viable alternative to antibiotics? Nature reviews, vol.11.

8. Shobharani, P \& Prakash M. Halami (2014). Cellular fatty acid profile and H+-ATPase activity to assess acid tolerance of Bacillus sp. for potential probiotic functional Attributes. Appl Microbiol Biotechnol, 98:90459058.

9. Snyder, A.B \& Worobo, R.W (2013). Chemical and genetic characterization of bacteriocins: antimicrobial peptides for food Safety. Society of Chemical Industry, Wiley Online Library. 